\title{
ANALISIS KINERJA KEUANGAN PERUSAHAAN PT SMARTFREN TELECOM, TbK MENGGUNAKAN METODE DU PONT
}

\author{
Amalia Rizky Damayanti ${ }^{1}$,Susanti Usman ${ }^{2}$, Ratih Juwita ${ }^{3}$ \\ Universitas Gunadarma \\ Email: amalia14@student.gunadarma.ac.id ${ }^{1}$, susantiusman208@gmail.com², \\ ratih_j@staff.gunadarma.ac.id ${ }^{3}$
}

\section{Abstrak}

Latar belakang: PT Smartfren Telecom, Tbk adalah operator penyedia jasa telekomunikasi berbasis teknologi CDMA yang memiliki lisensi selular dan mobilitas terbatas (Fixed Wireless Access), serta memiliki cakupan jaringan CDMA EV-DO (jaringan mobile broadband yang setara dengan $3 \mathrm{G}$ ) yang terluas di Indonesia.

Tujuan penelitian: untuk menganalisis kinerja keuangan yang diukur dengan metode Du Pont pada PT Smartfren Telecom, Tbk periode 2018-2020.

Metode penelitian: Metode Penelitian menggunakan metode Du Pont dengan variabel Net Profit Margin (NPM), Total Assets Turnover (TATO), Return On Investment (ROI), Equity Multiplier (EM), Return On Equity (ROE). Dalam penulisan ilmiah ini penulis menggunakan data sekunder, data yang diperoleh dari situs perusahaan Smartfren Telecom, Tbk yang bisa diakses pada https://www.smartfren.com dan situs Indonesia Stock Exchange (Bursa Efek Indonesia) yang bisa diakses pada https://www.idx.co.id. Data yang digunakan berupa laporan keuangan PT Smartfren Telecom, Tbk periode tahun 2018-2020.

Hasil penelitian: Net Profit Margin merupakan presentase dari rasio profitabilitas yang berfungsi untuk mengukur berapa besar laba bersih setelah pajak terhadap penjualan yang diperoleh perusahaan. NPM pada tahun 2018-2019 mengalami kenaikan sebesar 33,4\%, Hal ini terjadi karena adanya peningkatan pada penjualan dan laba bersih

Kesimpulan: bahwa dengan menggunakan metode Du Pont yang menggabungkan NPM, TATO, ROI, EM dan ROE, PT Smartfren Telecom, Tbk berada pada kinerja yang tidak baik.

Kata kunci: Metode Du Pont, Net Profit Margin (NPM), Total Assets Turnover (TATO), Return On Investment (ROI), Equity Multiplier (EM), Return On Equity (ROE), Kinerja keuangan

\section{Abstract}

Background: PT Smartfren Telecom, Tbk is a telecommunication service provider operator based on CDMA technology that has a cellular license and limited mobility (Fixed Wireless Access), and has the widest CDMA EV-DO network coverage (mobile broadband network equivalent to $3 G$ ) in Indonesia.

The purpose of the study to analyze financial performance as measured by the Du Pont method at PT Smartfren Telecom, Tbk for the period 2018-2020

Research method: The research method uses the Du Pont method with the variables Net Profit Margin (NPM), Total Assets Turnover (TATO), Return On Investment (ROI), Equity Multiplier (EM), Return On Equity (ROE). In scientific writing, the author uses secondary data, data obtained from the Smartfren Telecom, Tbk company website which can be accessed at https://www.smartfren.com and the Indonesia Stock Exchange (Indonesian Stock Exchange) website which can be accessed at https:// www.idx.co.id. The data used is in the form of the financial statements of PT Smartfren Telecom, Tbk for the period 2018-2020.

The results of the study: Net Profit Margin is a percentage of the profitability ratio which serves to measure how much net profit after tax on sales earned by the company. NPM in 2018-2019 increased by 33.4\%, this was due to an increase in sales and net profit.

Conclusion: that by using the Du Pont method which combines NPM, TATO, ROI, EM and ROE, PT Smartfren Telecom, Tbk is in poor performance

Keywords: Du Pont Method, Net Profit Margin (NPM), Total Assets Turnover (TATO), Return On Investment (ROI), Equity Multiplier (EM), Return On Equity (ROE), Financial

\begin{tabular}{ll}
\hline & Amalia Rizky Damayanti,Susanti Usman, Ratih Juwita. (2021). Analisis Kinerja Keuangan \\
& Perusahaan Pt Smartfren Telecom, Tbk Menggunakan Metode Du Pont. Co-Value: Jurnal \\
How to cite: & Ekonomi, Koperasi Kewirausahaan Vol12(2): 83-90 \\
E-ISSN: & https://greenpublisher.id/ \\
Published by: &
\end{tabular}




\section{PENDAHULUAN}

PT Smartfren Telecom, Tbk adalah operator penyedia jasa telekomunikasi berbasis teknologi CDMA yang memiliki lisensi selular dan mobilitas terbatas (Fixed Wireless Access), serta memiliki cakupan jaringan CDMA EV-DO (jaringan mobile broadband yang setara dengan 3G) yang terluas di Indonesia.(HIDAYAH, 2019) Smartfren juga merupakan operator telekomunikasi pertama di dunia yang menyediakan layanan CDMA EV-DO Rev. B (setara dengan 3,5G dengan kecepatan unduh s.d. 14,7 Mbps) dan operator CDMA pertama yang menyediakan layanan Blackberry.(Kusnindar, 2020) PT Smartfren Telecom, Tbk (smartfren) awalnya bernama PT Smart Telecom, Tbk dan PT Mobile-8 Telecom, Tbk (Mobile-8) sebelum bulan April 2010. PT Mobile-8 Telecom, Tbk awalnya dimiliki oleh PT Global Mediacom, Tbk.(NOVRIANI, 2019)

Jasa dan layanan Smartfren memiliki nilai-nilai (values) yaitu sebagai mitra yang terbaik bagi pelanggan dengan menawarkan solusi yang cerdas dalam layanan-layanan telekomunikasi untuk meningkatkan pengalaman hidup pelanggan dalam berkomunikasi.(Hermansyah, 2020) Sebagai operator CDMA yang menyediakan jaringan internet kecepatan tinggi bergerak (mobile broadband) yang terluas di Indonesia, Smartfren berkomitmen untuk menjadi penyedia layanan telekomunikasi yang terjangkau bagi masyarakat dengan kualitas terbaik.(ARTHA, n.d.)

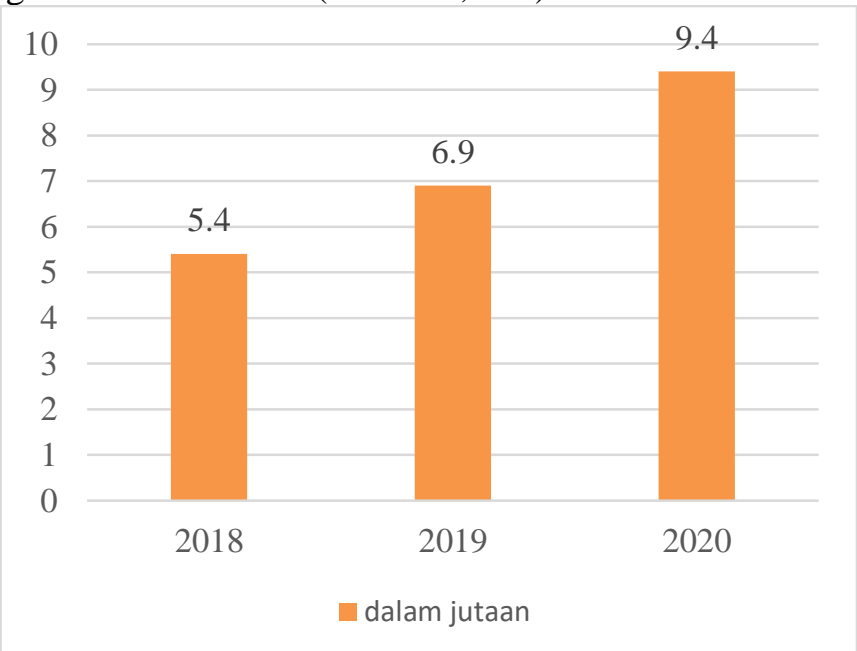

Gambar 1 Pendapatan PT Smartfren Telecom, Tbk Periode 2018-2020

Sumber : Laporan Keuangan PT Smartfren Telecom, Tbk

Berdasarkan laporan keuangan PT Smartfren Telecom, Tbk periode 2018-2020, perusahaan mengalami peningkatan yang cukup signifikan dari pendapatan sebesar Rp5,4 juta di tahun 2018 meningkat menjadi Rp6,9 juta di tahun 2019 sekitar 27,27\%, dan pada tahun 2019 sebesar Rp6,9 juta menjadi Rp9,4 juta di tahun 2020 sekitar 34,63\%. Hal ini terjadi karena meningkatnya penggunaan data internet sebagai dampak kebijakan Work From Home (WFH). Persaingan yang kompetitif di bidang telekomunikasi membuat PT Smartfren Telecom, Tbk harus terus berusaha memaksimalkan sumber daya dan meningkatkan kinerja keuangan perusahaan dari tahun ke tahun, terlihat bahwa perusahaan menunjukan kinerja keuangan yang kurang baik terlihat dari kerugian bersih yang diperoleh perusahaan selama tiga tahun terakhir.(Sibarani et al., 2021) 
PT Smartfren Telecom, Tbk sukses memperkecil kerugian selama masa pandemi Covid-19 berlangsung di tahun 2020. Pada laporan keuangan rugi bersih sebesar Rp1,52 juta atau lebih rendah 30,35\% dibanding tahun 2019 sebesar Rp2,18 juta. Oleh karena itu, walaupun pendapatan PT Smartfren Telecom, Tbk meningkat tetapi tetap memperoleh kerugian, disebabkan karena ada biaya biaya yang masih harus ditanggung perusahaan, termasuk untuk investasi dan ekspansi dalam perluasan jaringan.(Nasution, 2021)

\section{METODE PENELITIAN}

Objek penelitian yang diteliti dalam mengukur kinerja perusahaan adalah analisis metode Du Pont.(Jonathan, 2018) Sedangkan subjek penelitian dalam penulisan ilmiah ini adalah PT Smartfren Telecom, Tbk yang merupakan perusahaan yang bergerak di bidang jasa layanan telekomunikasi.(OKTARIANSYAH et al., 2020)

Jenis data yang digunakan pada penulisan ilmih ini adalah jenis data kuantitatif karena peneliti menggunakan data berupa angka yaitu Laporan Keuangan PT Smartfren Telecom, Tbk periode 2018-2020.(Purwati, 2021) Sumber data pada penelitian ini adalah data sekunder, data yang diperoleh dari situs perusahaan Smartfren Telecom, Tbk yang bisa diakses pada https://www.smartfren.com dan situs Indonesia Stock Exchange (Bursa Efek Indonesia) yang bisa diakses pada https://www.idx.co.id.(Saffarani, 2020) Data yang digunakan berupa laporan keuangan PT Smartfren Telecom, Tbk periode tahun 2018-2020

Teknik pengumpulan data yang dilakukan dalam penelitian ini adalah studi pustaka, yaitu dengan mempelajari berbagai sumber literatur ataupun dengan mengutip langsung seperti jurnal-jurnal penelitian yang bersangkutan, penelitian terdahulu, dan sumbersumber literatur lainnya yang bersangkutan dengan judul penelitian. Berikut adalah Jurnal yang digunakan peneliti sebagai referensi penulisan Ilmiah yaitu dari jurnal Manajemen Perpajakan, Jurnal Akuntansi Keuangan dan Bisnis, Jurnal Manajemen, dan Jurnal Administrasi dan Bisnis

Teknik analisis yang digunakan untuk melakukan perhitungan dengan menggunakan metode Du Pont adalah berupa lima rasio, yaitu :

1) Margin Laba Bersih / Net Profit Margin (NPM)

$$
N P M=\frac{\text { Laba Bersih setelah pajak }}{\text { Penjualan bersih }} \times 100 \%
$$

2) Perputaran Total Aktiva / Total Assets Turnover (TATO)

$$
\text { TATO }=\frac{\text { Penjualan bersih }}{\text { total assets }} \times 1 \mathrm{kali}
$$

3) Tingkat Pengembalian Atas Investasi / Return on Investment (ROI) $R O I=$ profit margin $x$ total assets turnover

4) Pengganda Ekuitas / Equity Multiplier

$$
\text { Equity Multiplier }=\frac{\text { Total aktiva }}{\text { Total ekuitas }} \quad \text { …............... }
$$

5) Tingkat Pengembalian Atas Ekuitas / Return on Equity (ROE)

$$
R O E=R O I x \text { Equity Multiplier }
$$




\section{HASIL DAN PEMBAHASAN}

\section{1) Net Profit Margin (NPM)}

Net Profit Margin merupakan presentase dari rasio profitabilitas yang berfungsi untuk mengukur berapa besar laba bersih setelah pajak terhadap penjualan yang diperoleh perusahaan.(SIHOTANG, 2021)

Tabel 2 Perhitungan Net Profit Margin PT Smartfren Telecom, Tbk Periode 2018-2020 (dalam jutaan rupiah)

\begin{tabular}{|c|c|c|c|}
\hline TAHUN & $\begin{array}{c}\text { Laba Bersih Setelah } \\
\text { Pajak }\end{array}$ & Penjualan & NPM \\
\hline 2018 & -3.552 .834 & 5.490 .311 & $-64,71 \%$ \\
\hline 2019 & -2.187 .772 & 6.987 .805 & $-31,31 \%$ \\
\hline 2020 & -1.523 .603 & 9.407 .883 & $-16,19 \%$ \\
\hline
\end{tabular}

Sumber : Data Olahan (2021)

NPM pada tahun 2018-2019 mengalami kenaikan sebesar 33,4\%, Hal ini terjadi karena adanya peningkatan pada penjualan dan laba bersih. Pada tahun 2018 jumlah penjualan sebesar Rp5.490.311 naik menjadi Rp6.987.805 di tahun 2019, serta laba bersih yang didapat lebih tinggi dari tahun sebelumnya, dari Rp -3.552.834 di tahun 2018 menjadi Rp -2.187.772 di tahun 2019 yang disebabkan karena penurunan pada beban penjualan sebesar Rp290.875, beban umum administrasi sebesar Rp763.576, serta kenaikan pada beban pajak sebesar Rp115.551 dan beban keuangan Rp231.359

NPM pada tahun 2019-2020 mengalami kenaikan sebesar 15,12\%. Hal ini disebabkan karena penjualan mengalami kenaikan dari tahun sebelumnya yang diikuti kenaikan laba bersih, tetapi presentase kenaikan laba bersih lebih kecil (naik 30,35\%) daripada presentase penjualan sekitar (naik 34,63\%) yang disebabkan karena penurunan pada beban penjualan sebesar Rp315.236, beban keuangan sebesar Rp475.760, beban umum dan administrasi sebesar Rp372.691, beban pajak sebesar Rp77.687.

\section{2) Total Assets Turnover (TATO)}

Total Assets Turnover merupakan rasio yang digunakan untuk mengukur perputaran semua aktiva yang dimiliki perusahaan dan mengukur berapa jumalah penjualan yang diperoleh dari tiap rupiah aktiva.(Alpi \& Gunawan, 2018)

Tabel 3 Perhitungan Total Assets Turnover PT Smartfren Telecom, Tbk Periode 2018-

$$
2020 \text { (dalam jutaan rupiah) }
$$

\begin{tabular}{|c|c|c|c|}
\hline TAHUN & Penjualan & Total Aktiva & TATO \\
\hline 2018 & 5.490 .311 & 25.213 .595 & 0,22 kali \\
\hline 2019 & 6.987 .805 & 27.650 .462 & 0,25 kali \\
\hline 2020 & 9.407 .883 & 38.684 .276 & 0,24 kali \\
\hline
\end{tabular}

Sumber : Data Olahan (2021)

TATO pada tahun 2018-2019 mengalami kenaikan sebesar 0,03 kali. Hal ini terjadi karena adanya kenaikan penjualan sebesar Rp1.497.494 yang diikuti dengan kenaikan total aktiva sebesar Rp2.436.867 yang diakibatkan oleh kenaikan aset tetap 
sebesar Rp3.147.448, serta adanya penurunan kas dan setara kas sebesar Rp208.775, persediaan sebesar Rp7.379, piutang sebesar Rp48.284

TATO pada tahun 2019-2020 mengalami penurunan yang tidak begitu besar sebesar 0,01 kali. Hal ini terjadi karena adanya kenaikan penjualan sebesar Rp2.420.078 yang diikuti dengan kenaikan total aktiva sebesar Rp12.470.681. tetapi presentase penjualan lebih kecil dibandingkan presentase total aktiva. Kenaikan total aktiva terjadi karena adanya kenaikan kas dan setara kas sebesar Rp457.685, aset tetap sebesar Rp9.778.471, piutang sebesar Rp36.953.

\section{3) Return On Investment (ROI)}

Return On Investment merupakan rasio yang menunjukkan kemampuan perusahaan menghasilkan laba dari aktiva yang digunakan. Hal ini mengidentifikasi seberapa besar total harta dimanfaatkan atau digunakan untuk mendapatkan keuntungan.(VIVI, 2022)

Tabel 4.Perhitungan Return On Investment PT Smartfren Telecom, Tbk Periode 20182020 (dalam jutaan rupiah)

\begin{tabular}{|c|c|c|c|}
\hline TAHUN & NPM & TATO & ROI \\
\hline 2018 & $-64,71 \%$ & 0,22 kali & $-14,24 \%$ \\
\hline 2019 & $-31,31 \%$ & 0,25 kali & $-7,83 \%$ \\
\hline 2020 & $-16,19 \%$ & 0,24 kali & $-3,88 \%$ \\
\hline
\end{tabular}

Sumber : Data Olahan (2021)

ROI pada tahun 2018-2019 mengalami kenaikan sebesar 6,41\%. Hal ini terjadi karena adanya peningkatan total aktiva sebesar Rp2.436.867 atau sekitar 9,66\%, disebabkan oleh aktiva tidak lancar yang lebih tinggi dibandingkan aktiva lancar. Rugi/laba bersih setelah pajak meningkat sebesar Rp1.365.062 atau sekitar 38,42\% yang disebabkan karena menurunnya beban penjualan sebesar Rp290.875, beban umum dan administrasi sebesar Rp763.577, beban pajak meningkat sebesar Rp115.551. ROI pada tahun 2019-2020 mengalami kenaikan sebesar 3,95\%. Hal ini terjadi karena adanya kenaikan dari rugi/laba bersih setelah pajak 1.365.062, disebabkan beban usaha naik 9,7\% dari Rp 9,29 triliun pada 2019 menjadi 10,19 triliun. Beban operasi, pemeliharaan dan jasa telekomunikasi naik menjadi 3,85 triliun pada 2020, Beban penjualan dan pemasaran naik menjadi Rp1,25 triliun pada 2020 dari periode sama tahun sebelumnya Rp939,36 miliar. Maka dari itu menyebabkan ROI di tahun 2020 lebih tinggi dari ROI tahun 2019.

\section{4) Equity Multiplier}

Equity Multiplier merupakan rasio yang menjelaskan seberapa jauh kemampuan perusahaan menginvestasi modal pada aktiva dengan menggunakan modal sendiri.(Putri \& Kencanawati, n.d.)

Tabel 5 Perhitungan Equity Multiplier PT Smartfren Telecom, Tbk Periode 20182020 (dalam jutaan rupiah)

\begin{tabular}{|c|c|c|c|}
\hline TAHUN & Total aktiva & Total ekuitas & EM \\
\hline 2018 & 25.213 .595 & 12.448 .006 & 2,03 kali \\
\hline 2019 & 27.650 .462 & 12.735 .487 & 2,17 kali \\
\hline 2020 & 38.684 .276 & 12.365 .889 & 3,13 kali \\
\hline
\end{tabular}

Sumber : Data Olahan (2021) 
EM pada tahun 2018-2019 mengalami kenaikan 0,14 kali. Hal ini terjadi karena naiknya jumlah aset sebesar Rp2.436.867 yang disebabkan menurunnya kas dan setara kas sebesar Rp208.927, persediaan sebesar Rp7.380, aset tak berwujud sebesar Rp895.491 yang disertai kenaikan jumlah ekuitas sebesar Rp287.481

EM pada tahun 2019-2020 mengalami kenaikan 0,96 kali. Hal ini terjadi karena naiknya jumlah aset sebesar Rp11.033.814 yang disebabkan naiknya kas dan setara kas sebesar Rp457.685, biaya dibayar dimuka Rp27.987, aset tetap Rp9.778.471 yang disertai jumlah ekuitas menurun sebesar Rp369.555 disebabkan turunnya jumlah ekuitas yang diatribusikan sebesar Rp369.543

\section{5) Return On Equity}

Return On Equity merupakan rasio mengukur kemampuan manajemen dalam mengelola capital yang ada untuk mendapatkan net income.(Ni'mah, 2018)

Tabel 6 Perhitungan Return On Equity PT Smartfren Telecom, Tbk Periode 2018 2020 (dalam jutaan rupiah)

\begin{tabular}{|c|c|c|c|}
\hline TAHUN & ROI & EM & ROE \\
\hline 2018 & $-14,24 \%$ & 2,03 kali & $-28,91 \%$ \\
\hline 2019 & $-7,83 \%$ & 2,17 kali & $-17 \%$ \\
\hline 2020 & $-3,88 \%$ & 3,13 kali & $-12,14 \%$ \\
\hline
\end{tabular}

Sumber : Data Olahan (2021)

ROE pada tahun 2018-2019 mengalami kenaikan sebesar 11,91\%. Kenaikan ini terjadi karena NPM naik yang disebabkan adanya penurunan pada beban penjualan sebesar Rp290.875, beban umum administrasi sebesar Rp763.576, serta kenaikan pada beban pajak sebesar Rp115.551 dan beban keuangan Rp231.359 serta naiknya pendapatan yang tidak begitu besar. Meningkatnya TATO karena TATO adanya kenaikan penjualan sebesar Rp1.497.494 yang diikuti dengan kenaikan total aktiva sebesar Rp2.436.867 yang diakibatkan oleh kenaikan aset tetap sebesar Rp3.147.448, serta adanya penurunan kas dan setara kas sebesar Rp208.775, persediaan sebesar Rp7.379, piutang sebesar Rp48.284, sedangkan EM meningkat karena naiknya jumlah aset sebesar Rp2.436.867 yang disebabkan menurunnya kas dan setara kas sebesar Rp208.927, persediaan sebesar Rp7.380, aset tak berwujud sebesar Rp895.491 yang disertai kenaikan jumlah ekuitas sebesar Rp287.481

ROE pada tahun 2019-2020 mengalmi kenaikan 4,86\%, karena terjadi kenaikan NPM yang disebabkan karena penjualan mengalami kenaikan dari tahun sebelumnya yang diikuti kenaikan laba bersih, tetapi presentase kenaikan laba bersih lebih kecil (naik $30,35 \%$ ) daripada presentase penjualan sekitar (naik 34,63\%) yang disebabkan karena penurunan pada beban penjualan sebesar Rp315.236, beban keuangan sebesar Rp475.760, beban umum dan administrasi sebesar Rp372.691, beban pajak sebesar Rp77.687, menurunnya TATO disebabkan adanya kenaikan penjualan sebesar Rp2.420.078 yang diikuti dengan kenaikan total aktiva sebesar Rp12.470.681, meningkatnya EM karena turunnya jumlah ekuitas yang diatribusikan sebesar Rp369.543

\section{KESIMPULAN}

Berdasarkan hasil rangkuman penelitian di atas, Net Profit Margin (NPM), Total Assets Turnover (TATO), Return On Investment (ROI), Equity Multiplier (EM), Return On Equity (ROE), masing-masing sebesar -37,40\%, 0,23kali, -8,65\%, 2,44 kali 
dan $-19,35 \%$. Secara keseluruhan tidak berada pada standar industri yang seharusnya. Sehingga dapat disimpulkan bahwa dengan menggunakan metode Du Pont yang menggabungkan NPM, TATO, ROI, EM dan ROE, PT Smartfren Telecom, Tbk berada pada kinerja yang tidak baik.

Hal ini terlihat pada Return On Investment selama tiga tahun walaupun mengalami peningkatan tetapi dibawah standard rasio rata-rata industri dan masih bernilai negatif artinya perusahaan masih kurang makmsimum dalam menghasilkan laba dengan aset yang dimiliki perusahaan sehingga kurang bersaing dengan perusahaan lain dalam menghasilkan laba.

Return On Equity selama tiga tahun mengalami peningkatan tetapi masih dibawah standard rasio rata rata industri dan bernilai negatif. Ini membuktikan bahwa perusahaan masih belum mampu menggunakan ekuitas perusahaan dengan baik karena ekuitas seperti modal disetor dan saldo laba cenderung menningkat sehingga laba bersih perusahaan yang didapatkan masih belum mampu menutup kerugian yang dimiliki perusahaan.

\section{BIBLIOGRAFI}

Alpi, M. F., \& Gunawan, A. (2018). Pengaruh current ratio dan total assets turnover terhadap return on assets pada perusahaan plastik dan kemasan. Jurnal Riset Akuntansi Aksioma, 17(2), 1-36.

ARTHA, A. L. (n.d.). PENGARUH KETIDAKPUASAN KONSUMEN, HARGA DAN KEBUTUHAN MENCARI VARIASI TERHADAP PERPINDAHAN MEREK MOBILE BROADBAND.

Hermansyah, A. (2020). Analisis Teknikal Pergerakan Harga Saham untuk Mengambil Keputusan Investasi pada Saham Sub Sektor Telekomunikasi yang Terdaftar Di Bursa Efek Indonesia. Universitas Islam Negeri Sultan Syarif Kasim Riau.

HIDAYAH, N. (2019). LAPORAN PRAKTIK KERJA LAPANGAN PADA PT SMARTFREN TELECOM, TBK.

Jonathan, I. B. (2018). Pengaruh Struktur Modal, Ukuran Perusahaan, Pertumbuhan Perusahaan Terhadap Kinerja Keuangan Pada Perusahaan Non Keuangan Dengan Menggunakan Dupont System. Jurnal Muara Ilmu Ekonomi Dan Bisnis, 2(2), 419426.

Kusnindar, R. A. (2020). Analisis fundamental sebagai dasar menentukan keputusan investasi saham subsektor telekomunikasi yang listing di BEI. Universitas Islam Negeri Maulana Malik Ibrahim.

Nasution, D. P. P. (2021). Analisis Modal Kerja Dengan Menggunakan Rasio Aktivitas Dan Rasio Likuidias Pada Perusahaan Telekomunikasi Indonesia Yang Terdaftar Dibursa Efek Indonesia Tahun 2016-2018. Kumpulan Karya Ilmiah Mahasiswa Fakultas Sosial Sains, 2(02).

Ni'mah, F. (2018). Pengaruh CAR, FDR, NPF, dan BOPO terhadap tingkat Profitabilitas (Return On Equity) pada PT. Bank Muamalat Indonesia Tbk. IAIN KENDARI.

NOVRIANI, E. (2019). IKLIM ORGANISASI DENGAN KEPUASAN KERJA PADA PROMOTOR DI PT SMARTFREN TELECOM TBK PALEMBANG. UIN RADEN FATAH PALEMBANG.

OKTARIANSYAH, D., Nazaruddin, A., \& Nailis, W. (2020). PENGARUH KUALITAS PELAYANAN TERHADAP KEPUTUSAN PEMBELIAN PADA OPERATOR SELULER SMARTFREN DI PALEMBANG. Sriwijaya University.

Purwati, R. (2021). ANALISIS RASIO LIKUIDITAS DAN SOLVABILITAS UNTUK 
MENGUKUR KINERJA KEUANGAN PADA PT ARWANA CITRAMULIA Tbk. PERIODE 2018-2020. Politeknik Harapan Bersama Tegal.

Putri, T. E., \& Kencanawati, M. S. (n.d.). ANALISIS KINERJA KEUANGAN MENGGUNAKAN SISTEM DU PONT PADA PERUSAHAAN TELEKOMUNIKASI YANG TERDAFTAR DI BURSA EFEK INDONESIA PERIODE 2015-2019.

Saffarani, T. T. (2020). ANALISIS PERBANDINGAN MODEL ALTMAN Z-SCORE, ZMIJEWSKI, SPRINGATE DAN GROVER DALAM MEMPREDIKSI KEBANGKRUTAN (STUDI EMPIRIS PERUSAHAAN TELEKOMUNIKASI DI INDONESIA). UNIVERSITAS NEGERI MAKASSAR.

Sibarani, M., Prabowo, A. G., \& Marjohan, M. (2021). Analisis Rasio Analisis Rasio Keuangan untuk Mengukur Kinerja Keuangan PT Smartfren Telecom, Tbk Tahun 2017-2019 untuk Mengukur Kinerja Keuangan PT Smartfren Telecom, Tbk Tahun 2017-2019. HUMANIS (Humanities, Management and Science Proceedings), 1(2).

SIHOTANG, A. V. (2021). ANALISIS RASIO PROFITABILITAS PADA PERUSAHAAN INDUSTRI SUB SEKTOR PULP DAN KERTAS YANG TERDAFTAR DI BURSA EFEK INDONESIA TAHUN 2017-2019.

VIVI, R. (2022). ANALISIS NET PROFT MARGIN (NPM), RETURN ON ASSET (ROA), OPERATING INCOME RETURN ON INVESTMENT (OIROI) TERHADAP ZAKAT PERUSAHAAN (Studi Kasus Bank Umum Syariah Yang Terdaftar Di Otoritas Jasa Keuangan 2016-2020). UNIVERSITAS ISLAM NEGERI RADEN INTAN LAMPUNG.

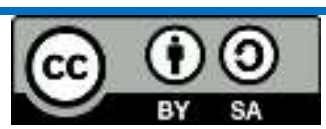

This work is licensed under a Creative Commons Attribution-ShareAlike 4.0 International License 